\title{
Wood density and tree size used as cues to locate and excavate cavities in two Colaptes woodpeckers inhabiting a threatened southern temperate forest of Argentina
}

\author{
Adrián Jauregui ${ }^{\text {a, }}$, Sabrina Andrea Rodríguez ${ }^{\mathrm{b}}$, Lucas Nahuel González García ${ }^{\mathrm{c}}$, \\ Exequiel Gonzalez ${ }^{\text {a }}$, Luciano Noel Segura ${ }^{a}$ \\ ${ }^{a}$ Sección Ornitología, División Zoología Vertebrados, Facultad de Ciencias Naturales y Museo, Universidad Nacional de La Plata, Argentina, Paseo del Bosque s/n, \\ B1900FWA, La Plata, Buenos Aires, Argentina \\ ${ }^{\mathrm{b}}$ Laboratorio de Investigación de Sistemas Ecológicos y Ambientales (LISEA), Facultad de Ciencias Agrarias y Forestales y Facultad de Ciencias Naturales y Museo-UNLP, \\ B1900FWA, Argentina \\ ${ }^{\mathrm{c}}$ Facultad de Ciencias Naturales y Museo, Universidad Nacional de La Plata, B1900, La Plata, Buenos Aires, Argentina
}

\section{A R T I C L E I N F O}

\section{Keywords:}

Campo Flicker

Colaptes campestris

Colaptes melanochloros

Green-barred Woodpecker

Nest-tree

Nest-site selection

\begin{abstract}
A B S T R A C T
Nest-site selection is crucial for birds' breeding success and, therefore, studies on this topic are critical in order to understand what features species need. This is particularly important in areas with conservation issues, where habitats and/or trees with the required features may be scarce. However, little information is available on the nest-site selection patterns of woodpeckers breeding in southern temperate forests, where tree logging considerably reduced forest cover and, hence, availability of trees suitable for cavity excavation. In addition, previous studies did not include assessments at different spatial scales nor including quantitative wood density data. Therefore, the main objective of this study is to assess nest-site selection patterns (at the habitat and cavity-tree scales) of the Campo Flicker Colaptes campestris and the Green-barred Woodpecker C. melanochloros breeding in a threatened southern temperate forest of central-east Argentina. Moreover, we report the first wood density data of the trees used by these two woodpeckers when excavating cavities and assess niche partitioning by comparing their cavities and cavity-trees to one another. To assess selection at a habitat scale (recording forest cover and edge of stands and trees), we compared selected breeding habitats to randomly found habitats. At a tree-scale (recording tree height, diameter, wood density and wood decay status), we compared cavity-trees to randomly found trees. Most cavities were excavated in medium (DBH $=20-35 \mathrm{~cm})$ or large $(>35 \mathrm{~cm})$ size trees with wood density $<0.5 \mathrm{~g} / \mathrm{cm}^{3}$. Generalized linear models indicated that woodpeckers' propensity to excavate a new cavity was negatively correlated with tree wood density (which was negatively correlated to wood decay status) and positively to tree size. Both woodpecker species focused more importantly on tree features compared to habitat features when excavating cavities. Because forest patches containing mid- and large-sized trees with main stems and/or branches with wood softened by decay processes have become less abundant in these forests due to uncontrolled logging actions, we emphasize the need to conserve trees with these characteristics to ensure the availability of the preferred features of these woodpeckers.
\end{abstract}

\section{Introduction}

Birds nest-site selection is a crucial part of birds breeding performance as it determines food availability and nest exposure to threats, both affected by processes acting at different spatial scales (Götmark et al. 1995, Jones 2001). For woodpeckers, the area selected to nest is essential because habitat features influence breeding success (Bonnot et al. 2009, Kozma and Kroll 2011, Zhu et al. 2012, Berl et al. 2014). Accordingly, areas with greater forest cover may be preferred because they hide the nest from predators/competitors (Brightsmith 2005, Bonnot et al. 2009) and provide greater food resources (Kozma and Kroll 2011). At a narrower scale, woodpeckers require trees large enough to fit their cavities (Lammertink and Estrada 1995), and may also prefer large trees to protect the cavity from predators (Zhu et al. 2012) and

\footnotetext{
* Corresponding author.

E-mail address: adrijaureguic@gmail.com (A. Jauregui).
} 
thermally isolate it (Nyirienda et al. 2016).

Most studies have revealed that, as a general rule, woodpeckers prefer to excavate snags with decaying wood, when the excavation process is facilitated because the wood is softened (Schepps et al. 1999, Masuoka 2008, Lorenz et al. 2015). However, most studies assessed wood decay status using visual categories (Schepps et al. 1999, Vierling et al. 2008, Wightman et al. 2010, Cockle et al. 2012) but not quantitative measurements. Recent studies have addressed this issue by quantifying wood hardness using an increment borer adapted to measure the torque required to make it spin inside the snag (Matsuoka 2008, Lorenz et al. 2015). Wood hardness is a property that determines the resistance to penetration of objects of great strength and consistency inside the wood or stems and is highly correlated to wood density under natural conditions (Rodriguez et al. 2021). Hence, because determining wood hardness may be a complicated procedure, determining wood density using a common unmodified increment borer (as used in ecology) would provide values that could be more easily used in other studies. Moreover, since wood density is an integrative variable related to demographic patterns and many architectural and physiological tree features (van Gelder et al. 2006, Chave et al. 2009), and much more studied and measured in tree ecology (compared to wood hardness), it is a proper feature to assess tree status. The density of the wood could vary between 0.1 (softest) and $1.5 \mathrm{~g} / \mathrm{cm}^{3}$ (hardest) (Chave et al. 2009). In a subtropical forest, where wood density ranged from $0.36 \mathrm{~g} / \mathrm{cm}^{3}$ to 0.73 $\mathrm{g} / \mathrm{cm}^{3}$, wood hardness ranged between $615 \mathrm{~N}$ and $4365 \mathrm{~N}$ (Rodríguez et al. 2021). Moreover, Lorenz et al. (2015) reported values between 0.0 and $6.6 \mathrm{Nm}$ for woodpeckers cavity-trees wood hardness and between 0.0 and $27.6 \mathrm{Nm}$ for random trees wood hardness in a temperate forest of North America.

Availability of wood appropriate for excavation is crucial for woodpeckers, specially for weak excavators, such as the Colaptes species, which capabilities to excavate wood are limited. This becomes more relevant in temperate forests, where the wood density range is shorter compared to tropical-subtropical forests, as a result of a lower tree species diversity (Chave et al. 2009), hence, appropriate wood might be scarce. However, for southern temperate forests, where the two most frequent Colaptes species are the sympatric Green-barred Woodpecker (Colaptes melanochloros) and the Campo Flicker (Colaptes campestris), the importance of wood density during the selection process to excavate a cavity is unknown. Moreover, given this natural narrow wood density offer in temperate forests, which is decreased by the degradation process under which South American forests are (Asner et al. 2005), these woodpeckers might be competing for resources when breeding in the same area.

Most of the background research on woodpeckers' nest-site selection was carried in the Northern Hemisphere. For South American woodpeckers, nest-site selection assessments including different spatial scales and quantitative wood density data are still lacking (but see Cockle et al. 2011, Ojeda et al. 2021). Our main objective is to assess the nest-site selection patterns at two spatial scales, because both birds distribution and habitat use could be related to processes involving both habitat features (e.g., fragmentation) and tree features (e.g., tree size). The study objects were populations of the Green-barred Woodpecker and the Campo Flicker breeding in a southern temperate forest of central-east Argentina, which has conservation concerns due to selective tree logging (Arturi and Goya 2004). We evaluate if the woodpeckers select features: 1) at a habitat scale, by comparing selected breeding sites to randomly found sites; and 2) at a tree-scale, by comparing cavity-trees to randomly found trees. In addition, we aim to provide information on the wood density threshold under which these two Colaptes species are excavating their cavities in a temperate forest to provide crucial information to forest managers. Finally, we compare these woodpeckers' cavities and cavity-trees (including their wood densities) to assess potential niche overlap and discuss whether they are competing for cavity excavation. More fragmented areas increase the chance of a nest being detected by competitors and predators (Brightsmith 2005, Bonnot et al.
2009). Hence, at a habitat scale, we predict that the probability of an area being selected will be positively related to forest cover, measured as tree cover, and negatively to forest edge, measured as the edge of stands and trees, both recorded at a fixed radius plot. At a tree scale, woodpeckers need trees large enough to fit their cavities. In addition, larger trees are less likely to brake against adverse climate conditions and more likely to provide more protection against predators. Therefore, we predict a specific tree selection probability will be positively related to tree size and negatively to wood density.

\section{Methods}

\subsection{Study site and species}

The study was conducted in a 1250 ha private ranch ('Luis Chico'; $35.3219^{\circ} \mathrm{S}, 57.2044^{\circ} \mathrm{W}, 8 \mathrm{~m}$ above sea level) located in northeastern Buenos Aires Province, Argentina (Fig. 1), within the 'Bahía de Samborombón' wildlife refuge (Organismo Provincial para el Desarrollo Sostenible). The ranch is a temperate flatland area composed of grasslands and semi-open forest patches (locally known as 'talares') formed continuously over calcareous material (fossil shells) and disposed as 'rows' parallel to the La Plata river, or as isolated patches (Fig. 1). The community of 'talares' tree species is found over the 'rows' while grasslands develop in the space between 'rows'. Forests represent only $\sim 15 \%$ of the total farm area due to permanent selective tree logging for firewood (Arturi and Goya 2004) (Fig. 1). Of the total surface covered by trees, $\sim 65 \%$ is composed of Celtis tala and $\sim 10 \%$ of Scutia buxifolia, two native species. Patches close to the river are dominated by $S$. buxifolia, while in more continental patches both species are equally represented. Isolated patches, far from the river, are dominated by $C$. tala., and this distribution could be due to differences in environmental requirements of the two species. These native trees density is $\sim 700 \mathrm{ind} /$ ha (Arturi and Goya 2004), being mainly ( $~ 85 \%$ ) small trees (diameter at breast height $[\mathrm{DBH}] \leq 20 \mathrm{~cm})$, whereas mature medium $(\mathrm{DBH}=20-35 \mathrm{~cm})$ and large (DBH $>35 \mathrm{~cm}$ ) size trees comprise $\sim 15 \%$ of the total native trees (A. Jauregui, unpubl. data). The rest of the forest area $(\sim 25 \%)$ is composed of the exotics Eucalyptus sp., Populus sp., Melia azedarach, Gleditsia triacanthos and the natives' Erythrina crista-galli and Schinus longifolius, being a mixture of large size trees (DBH $>35 \mathrm{~cm}$ ) and small- and medium-sized trees (DBH $\leq 35 \mathrm{~cm}$ ) (A. Jauregui, unpubl. data). S. buxifolia and C. tala have the hardest wood in the area (mean dry (i.e., basic) wood densities are 1.06 and $0.81 \mathrm{~g} / \mathrm{cm}^{3}$ respectively; Atencia 2003). Eucalyptus sp., G. triacanthos, and S. longifolius represent intermediate trees within the wood density spectrum of the area (mean dry wood densities $0.78,0.67$ and $0.67 \mathrm{~g} / \mathrm{cm}^{3}$, respectively; Atencia 2003). The trees with the softest wood are $M$. azedarach, Populus sp., and E. crista-galli (mean dry wood densities $0.48 \mathrm{~g} / \mathrm{cm}^{3}, 0.42 \mathrm{~g} / \mathrm{cm}^{3}$ and 0.25 $\mathrm{g} / \mathrm{cm}^{3}$ ) (Atencia 2003).

The Green-barred Woodpecker and the Campo Flicker are two sexually dimorphic primary cavity nesters that can either excavate new cavities or reuse old ones. Cavities can be located on the main stem of snags, on snags branches or even on light posts and termitaria (Winkler and Christie 2002, Dias et al. 2013). Both woodpeckers have an insectbased diet, mainly ants, and can forage on the ground and the trees (Winkler and Christie 2002). In the study area, their breeding season lasts from late-September to mid-January. The birds have clutch sizes of $\sim 4$ eggs, and will rear $\sim 2$ fledglings when successful (Jauregui 2020). The main cause of nest failure in the study area is depredation (Segura and Reboreda 2012, Gonzalez et al. 2019), which for these two woodpeckers causes $\sim 60 \%$ of nest failures (Jauregui 2020).

\subsection{Field methods}

We searched for new cavities (i.e., recently excavated to nest) of the Campo Flicker and the Green-barred Woodpecker during the 2017/2018 breeding season (Austral spring and early summer). New cavities 


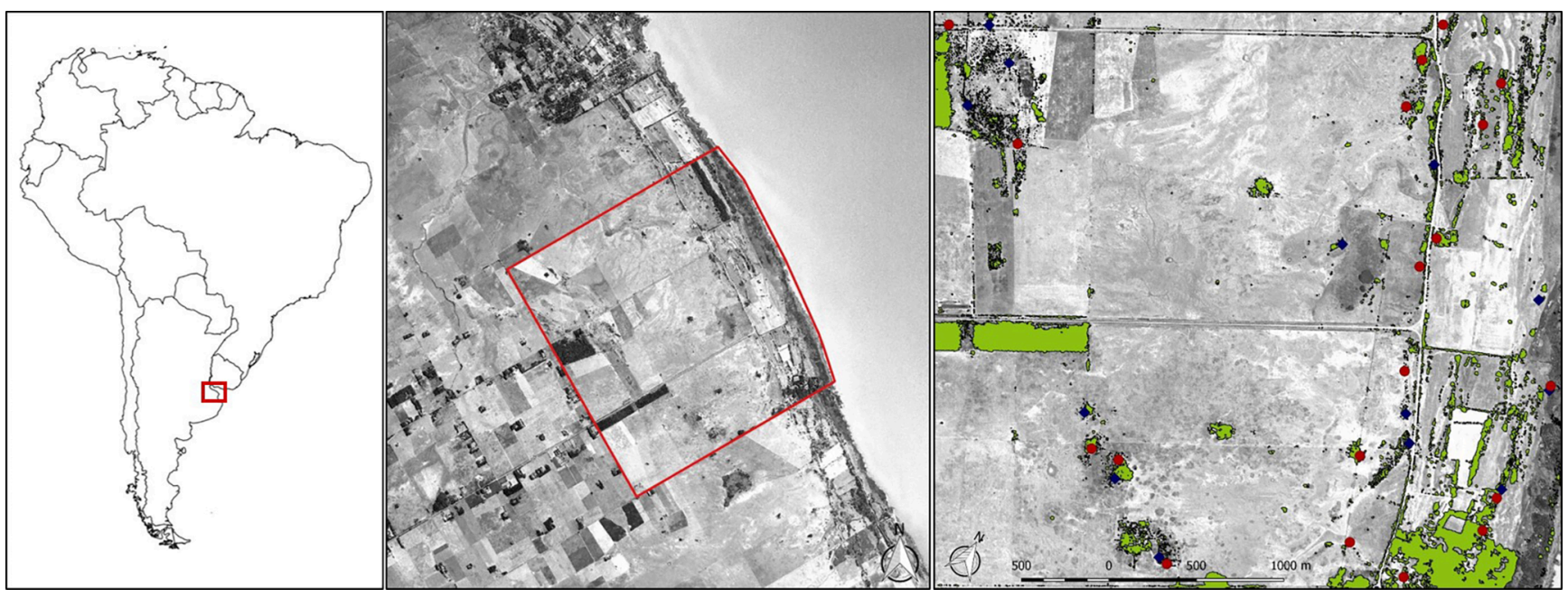

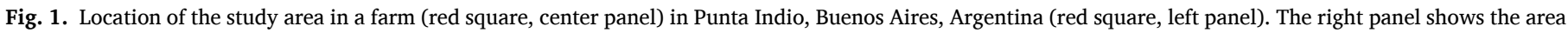

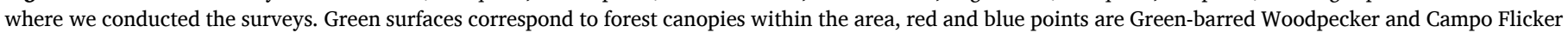
cavity-trees, respectively. (For interpretation of the references to colour in this figure legend, the reader is referred to the web version of this article.)

surveys were primarily in September and October, which is the moment when woodpeckers are excavating their cavities in these latitudes (Jauregui 2020). We walked through every forested area (continuous forests, isolated patches and lonely trees) within the study site every three days to find breeding pairs excavating cavities. We found new cavities by observing breeding pairs entering or leaving cavities, by listening to individuals pecking the wood and/or by checking for wood chips on the ground immediately under a cavity entrance hole (i.e., evidence of recent wood pecking activity). Breeding attempts in old cavities (i.e., not excavated in the $2017 / 2018$ breeding season) were discarded. We reached the cavity climbing and using a $5 \mathrm{~m}$ ladder and monitored it using a mirror and a flashlight. We considered an active nest whenever we observed eggs or nestlings, and we geolocated nests using a GPS.

For each cavity-tree, we recorded features that we believed could have been selected by the woodpeckers, according to previous studies (Table 1). At a habitat scale, we first defined that both stands (i.e., groups of trees from different species and sizes), and individual trees,

Table 1

Features used to assess nest-site selection of two Colaptes woodpeckers breeding in central-east Argentina, according to previous studies.

\begin{tabular}{|c|c|c|}
\hline Feature & Explanations & References \\
\hline $\begin{array}{l}\text { Tree size [height and } \\
\text { diameter at breast } \\
\text { height] }\end{array}$ & $\begin{array}{l}\text { Larger trees are a barrier for terrestrial } \\
\text { predators, resist heavy weather and/or } \\
\text { maximize thermal insulation. }\end{array}$ & $\begin{array}{l}{[1] ;[2] ;[3] ;} \\
{[4]}\end{array}$ \\
\hline $\begin{array}{l}\text { Tree status [wood } \\
\text { density] }\end{array}$ & $\begin{array}{l}\text { Softer wood favours the excavation } \\
\text { process, under a threshold. }\end{array}$ & {$[5] ;[6] ;[7]$} \\
\hline Habitat [forest cover] & $\begin{array}{l}\text { a) Greater forest cover protects fledglings } \\
\text { from predators and provides greater food } \\
\text { resources.b) Lesser forest cover increases } \\
\text { the chance to observe predators before } \\
\text { they reach the cavity. }\end{array}$ & $\begin{array}{l}\text { a) }[8][9] \\
\text { b) }[10] ;[11]\end{array}$ \\
\hline Habitat [forest edge] & $\begin{array}{l}\text { Higher forest edge (which implies more } \\
\text { fragmentation) increases nest } \\
\text { detectability by predators or by cavity } \\
\text { competitors. }\end{array}$ & $\begin{array}{l}{[12] ;[13] ;} \\
{[14]}\end{array}$ \\
\hline Habitat [shape index] & $\begin{array}{l}\text { Predators' movements are favoured as } \\
\text { shape increases. }\end{array}$ & [12][14] \\
\hline
\end{tabular}

[1]van Gelder et al. 2006; [2]Domokos and Cristea 2014; [3]Nappi et al. 2015; [4]Nyirenda et al. 2016; [5]Matsuoka 2008; [6]Zhu et al. 2012; [7]Lorenz et al. 2015; [8]Gow and Wiebe 2014; [9] Tremblay et al. 2014; [10]Anderson and LaMontagne 2016; [11]Chotprasertkoon et al. 2017;

[12]Deng and Gao 2005; [13]Denny and Summers, 1996; [14]Le Tortorec et al. 2013. were the 'forest'. We then recorded forest features (cover and edge) within a $100 \mathrm{~m}$ diameter circle (centred on the cavity-tree) using QGIS 3.8 (QGIS Development Team 2018) through a SPOT6 satellite image (1.5 m spatial resolution) provided by the Comisión Nacional de Actividades Espaciales (CONAE). By choosing a circle this size, we aimed to account for landscape configuration and to record features inside woodpecker territories (Dias et al. 2013, Jauregui 2020). We considered forest cover as the number of pixels corresponding to tree canopies within the circle and edge as the pixels corresponding to stands or individual trees edges within the circle. In addition, to account for forest configuration, we estimated the shape index as $P / 2^{*} \sqrt{ } \pi^{*} \mathrm{~F}$, where $\mathrm{P}$ is edge and $\mathrm{F}$ is forest cover. This unitless index compares forest shape to a standard shape (here a circle), and as it increases, the forest is more irregular (i.e. core area diminishes; Rutledge 2003). To determine each tree species availability, we recorded the number and species of trees in the surroundings of cavity-trees (within an $11.3 \mathrm{~m}$ circle, centred on the cavity-tree).

At a tree scale, we recorded $\mathrm{DBH}$, tree height, and species of the cavity-tree. We also determined wood density, by taking $15 \mathrm{~cm}$ long samples from the trees (average length of woodpecker cavities at the study site; Jauregui 2020), using a Pressler's borer (HAGLÖF). We took the sample from $5 \mathrm{~cm}$ above the cavity entrance or $10 \mathrm{~cm}$ beneath the cavity chamber (Matsuoka 2008, Lorenz et al. 2015). Wood samples were saturated with distilled water for $72 \mathrm{~h}$, and we determined saturated weight and volume following Scholz et al. (2007). Afterward, we dried samples using a stove at $70^{\circ}$ for $72 \mathrm{~h}$ to determine dried weight. Dry wood density was calculated as $\mathrm{M} / \mathrm{V}$, where $\mathrm{M}$ is dry mass, and V is the green volume of the sample. In addition, wood samples were assigned one of three visually identifiable degradation categories, classified as: $\mathrm{A}=$ healthy pieces, $\mathrm{B}=$ partially degraded pieces, and $\mathrm{C}=$ considerably degraded pieces (Supplementary Figure S1). We could not measure wood density for all wood pieces because some of them were fully degraded ( $n=10$ cavity-tree and four random-tree pieces, all from C. tala assigned to ' $\mathrm{C}$ ' degradation category; Supplementary Material Figure S1). As some of the other pieces from C. tala assigned with the ' $\mathrm{C}$ ' degradation category wood density could be determined, we assumed degraded pieces had lower wood density than the lowest determined value $\left(0.33 \mathrm{~g} / \mathrm{cm}^{3}\right.$ for C. tala). Hence, for degraded pieces we used a random wood density value between 0.1 (among the lowest wood density values in nature) and $0.33 \mathrm{~g} / \mathrm{cm}^{3}$.

To compare the woodpeckers' cavities, at a cavity-scale we recorded: 1) cavity entrance maximum and minimum diameter; 2) cavity depth and length; and 3) cavity location within the tree (main stem, primary 
branch, or secondary branch). Cavity length was the distance between the inner part of the entrance hole and the tree wall opposite to it. Cavity depth was the distance between the lowest limit of cavity entrance and cavity floor. Afterward, we estimated cavity volume as the product of cavity depth and cavity floor area (adapted from Wiebe and Swift 2001), where cavity floor was modelled as a circle. Therefore its area was $\pi^{\star} r^{2}$; where $r$ is half of the cavity length. We recorded every feature after the breeding season was over.

\subsection{Nest-site selection and analysis}

To assess nest-site selection at a habitat scale, we compared used habitats to available (i.e., potentially selectable) habitats. To find available habitats, we first created random points (using QGIS) inside the study area, which amount corresponded to the amount of cavitytrees of each woodpecker species. Any given snag being the closest to the random point with a $\mathrm{DBH} \geq 17 \mathrm{~cm}$, which was the minimum $\mathrm{DBH}$ used by the woodpeckers during the two previous breeding seasons, was selected as an available snag. Once we found the available snag, we draw a $100 \mathrm{~m}$ circle (centred on the snag) and measured the same features (forest cover, edge and shape index) than for used habitats for comparisons. Since it has been reported a territorial behavior in the Campo Flicker (Dias et al. 2013), and our personal observations indicate both species have a territorial behavior, a habitat was considered available if there was no considerable ( $>30 \%$ ) overlap between the 'used habitat' and 'available habitat' circles. Following this procedure, we established 13 available habitats for the Campo Flicker and 14 for the Green-barred Woodpecker. Although there were largely forested areas within the study area (Fig. 1), these were exotic trees plantations which did not count with snags for woodpeckers to excavate and (probably as a consequence) we never found a woodpecker nest, hence, these areas were not considered as 'available'. We evaluated whether habitat features influenced the likelihood of an area being selected using GLMs with a binary response variable $(0=$ available habitat; $1=$ used habitat $)$ and a logit link function. Habitat features were included as explanatory variables and we ran seven models which included all combinations between the recorded variables at this scale.

To assess nest-site selection at a tree scale, we compared cavity-trees to randomly found available snags. We found available snags by walking in a random direction and distance up to $100 \mathrm{~m}$ from the cavity-tree (i.e., inside woodpeckers' territories; Dias et al. 2013). This design assumes breeding pairs select a breeding territory and search for a nesting tree after (Battin and Lawler 2006). Any given snag being the closest to the random location and that met the same criteria than for the habitat scale snag (see above), was selected as an available snag. For each available snag, we measured the same features described for cavity-tree for comparisons and wood samples to determine wood density of available snags were taken from a random point within the tree (Lorenz et al. 2015). Preliminary results indicated that most cavities were in C. tala ( $\sim 80 \%$ ), hence, we decided to exclude the variable 'tree species' from the set of models. Instead, we assessed if used tree species was independent of tree species availability by performing a chi-square goodness-of-fit test (Jelinski 1991) comparing cavity-tree species abundance to overall tree species abundance. Tree species with $<2 \%$ abundance were grouped in a unique 'other species' category. To assess nest-site selection at a tree scale, we used GLMMs with a binary response variable $(0=$ available snag; $1=$ cavity-tree $)$ and a logit link function. Sites' features were included as explanatory variables, and to account for cavity-trees and available trees being paired (as designed), each pair was included as a random-effects factor to mitigate differences across sites (Anderson and LaMontagne 2016). Although both species can excavate trees with $\mathrm{DBH}=17 \mathrm{~cm}$ (Jauregui 2020), they may prefer larger trees to excavate a cavity (Bonnot et al. 2009, Zhu et al. 2012), which have become less abundant in the area because of tree logging. Hence, we included a quadratic form of $\mathrm{DBH}$, to assess species suitability to choose trees an intermediate size (Bonnot et al. 2009). We ran a total of seven models which included simple effects of all variables, one including 'tree size' variables (Table 1), and a global model including all variables (Supplementary Material Table S1 for full model set). We also assessed if the amount of pieces assigned to the degradation categories (A, B, C) was different between cavity-trees and available trees, using a Chi-squared test.

We compared the woodpecker cavities and cavity-trees using a GLM with a binary response $(0=$ Campo Flicker; $1=$ Green-barred Woodpecker) with a logit link function. Features were used as explanatory variables. Also, to assess differences between the species regarding cavity location within the tree (main stem, primary branch, secondary branch), we used a chi-square tests (Jelinski 1991), respectively. We considered differences to be significant if $P<0.05$.

Before running the analysis, we centred and standardized every variable to allow direct comparisons between the estimates. In addition, we checked for collinearity and multicollinearity between the recorded variables using Pearson's correlation and the Variance Inflation Factor (VIF), respectively (Battin and Lawler 2006). Variables were considered correlated if the correlation coefficient $(r)$ was $\geq 0.7$ and multicollinearity when VIF $\geq 10$ (Dormann et al. 2013). There was no correlation between any of the variables recorded in the study (including cross-scale comparisons; Supplementary Figure S2), except for wood density and wood samples degradation category (see Results).

We used an information-theoretic approach (Burnham and Anderson 2002) to assess models support to the data and compared models using Akaike's Information Criterion corrected for small sample sizes $\left(\mathrm{AIC}_{\mathrm{C}}\right)$ and Akaike weight ( $w$ ) (Burnham and Anderson 2002). If none of models received $w>0.9$ support (i.e., one model receiving considerable support), we addressed model selection uncertainty by averaging the models accounting $w>0.9$ (Burnham and Anderson 2002). We used the 'zero averaging method' (see Grueber et al. 2011 for details) and assumed that a variable was considerably influencing selection likelihood if the $95 \%$ confidence interval on its odd ratio did not include one. All analyses were performed in R 3.5.1 ( $\mathrm{R}$ Development Core Team 2018) and we used lme4 package for mixed models (Bates et al. 2015). Values presented are mean \pm SE.

\section{Results}

We found 31 new cavities (13 of the Campo Flicker and 18 of the Green-barred Woodpecker; Tables 2 and 3). Cavities were $79 \%$ on C. tala, $6 \%$ on E. crista-galli, $6 \%$ on Populus spp., $3 \%$ on Melia azedarach, $3 \%$ on Acacia melanoxylon and 3\% on Eucalyptus spp. From the total available trees registered ( $n=273$ trees), $66 \%$ were C. tala, $12 \%$ S. buxifolia, $3 \%$ Populus sp., $4 \%$ E. crista-galli, and $15 \%$ other species. Tree species were used according to their availability $\left(\chi^{2}=4.9, \mathrm{df}=4, P\right.$ $=0.29$ ).

Campo Flicker cavities were in habitats with less forest edge, compared to available habitats, while the Green-barred Woodpecker excavated in areas with greater forest cover compared to available habitats (Table 2). However, at a habitat scale, none of the models received considerable support for both species and the null model (with no explanatory variables) was among the top models (Table 3).

Available snags had harder wood density compared to cavity-trees of both species (Table 2), hence, there was a negative relationship between wood density and the likelihood of a tree being selected (Fig. 2). At a tree-scale, the model including the simple effect of wood density was among the top fitting models for both species, although it received considerably more support for the Green-barred Woodpecker (Table 3). The model including the quadratic form of DBH was the top model in the Campo Flicker model set and this variable was also among the top models in the Green-barred Woodpecker (Table 3). Both species showed a tendency to select medium-sized trees, but more markedly did the Campo Flicker (Fig. 2). Nevertheless, none of the variables included one within their odds ratio confidence intervals (Table 4). Out of the total cavity-tree wood pieces, two were healthy (A), 17 were partially 
Table 2

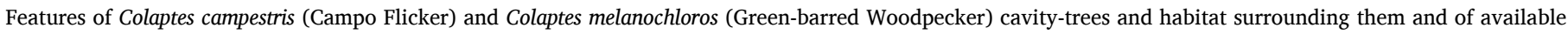
trees and habitats in a southern temperate forest of central-east Argentina.

\begin{tabular}{|c|c|c|c|c|c|c|c|c|}
\hline \multirow[t]{2}{*}{ Woodpecker } & \multirow[t]{2}{*}{ Scale } & \multirow[t]{2}{*}{ Feature } & \multicolumn{3}{|l|}{ Cavity-tree } & \multicolumn{3}{|l|}{ Available } \\
\hline & & & Mean \pm SE & Range & $\mathrm{n}$ & Mean \pm SE & Range & $\mathrm{n}$ \\
\hline \multirow[t]{6}{*}{ Campo Flicker } & \multirow[t]{3}{*}{ Habitat } & Forest cover (ha) & $0.7 \pm 0.1$ & $0.1-1.3$ & 13 & $0.7 \pm 0.1$ & $0.3-1.1$ & 13 \\
\hline & & Forest edge $(\mathrm{km})$ & $2.2 \pm 0.3$ & $0.7-5.0$ & 13 & $2.8 \pm 0.4$ & $0.4-5.2$ & 13 \\
\hline & & Shape index (unitless) & $1.0 \pm 0.2$ & $0.1-2.6$ & 13 & $1.0 \pm 0.1$ & $0.2-1.7$ & 13 \\
\hline & \multirow[t]{3}{*}{ Tree } & Tree height $(\mathrm{m})$ & $5.8 \pm 0.5$ & $3.7-8.9$ & 13 & $6.0 \pm 0.6$ & $2.5-10.5$ & 13 \\
\hline & & $\mathrm{DBH}(\mathrm{cm})$ & $35.5 \pm 2.4$ & $22.1-45.2$ & 13 & $37.5 \pm 4.8$ & $16.2-62.4$ & 13 \\
\hline & & Wood density $\left(\mathrm{g} \mathrm{cm}^{3}-1\right)$ & $0.32 \pm 0.04$ & $0.15-0.64$ & 13 & $0.47 \pm 0.05$ & $0.19-0.66$ & 13 \\
\hline \multirow[t]{6}{*}{ Green-barred Woodpecker } & \multirow[t]{3}{*}{ Habitat } & Forest cover (ha) & $0.9 \pm 0.1$ & $0.3-2.4$ & 18 & $0.7 \pm 0.1$ & $0.2-1.2$ & 14 \\
\hline & & Forest edge $(\mathrm{km})$ & $2.2 \pm 0.2$ & $0.8-4.8$ & 18 & $1.9 \pm 0.2$ & $0.4-3.7$ & 14 \\
\hline & & Shape index (unitless) & $1.2 \pm 0.2$ & $0.3-3.9$ & 18 & $0.8 \pm 0.1$ & $0.1-1.8$ & 14 \\
\hline & \multirow[t]{3}{*}{ Tree } & Tree height (m) & $6.4 \pm 0.6$ & $2.1-13.8$ & 18 & $5.4 \pm 0.7$ & $2.1-11.5$ & 18 \\
\hline & & $\mathrm{DBH}(\mathrm{cm})$ & $34.0 \pm 3.1$ & $17.9-62.5$ & 18 & $41.3 \pm 5.4$ & $16.2-98.4$ & 18 \\
\hline & & Wood density $\left(\mathrm{g} \mathrm{cm}^{3}-1\right)$ & $0.34 \pm 0.03$ & $0.15-0.58$ & 18 & $0.47 \pm 0.03$ & $0.24-0.70$ & 18 \\
\hline
\end{tabular}

Table 3

Top candidate models to assess nest-site selection of the Campo Flicker and the Green-barred Woodpecker in central-east Argentina. We present models summing 0.9 of $w$ or those above the null model. Full data sets are in Supporting Online Information Table S1. $k=$ number of parameters; $\mathrm{AIC}_{\mathrm{c}}=$ Akaike's Information Criterion corrected for small samples; $\Delta=$ differences in $\mathrm{AIC}_{\mathrm{c}}$ between models; $w=$ AIC weight.

\begin{tabular}{lllllll}
\hline Woodpecker & Scale & Model & $k$ & AIC $_{\mathrm{c}}$ & $\Delta$ & $w$ \\
\hline Campo Flicker & \multirow{2}{*}{ Habitat } & $\mathrm{C}+\mathrm{E}+\mathrm{S}$ & 4 & 37.9 & 0.0 & 0.25 \\
& & Null & 1 & 38.2 & 0.3 & 0.21 \\
& \multirow{2}{*}{ Tree } & DBH $+\mathrm{DBH}^{2}$ & 5 & 34.6 & 0.0 & 0.46 \\
& & WD & 4 & 35.3 & 0.7 & 0.31 \\
& Null & 3 & 37.8 & 3.2 & 0.09 \\
Green-barred & Habitat & C & 2 & 40.6 & 0.0 & 0.25 \\
Woodpecker & & S & 2 & 40.9 & 0.3 & 0.21 \\
& \multirow{4}{*}{ Tree } & Null & 1 & 41.0 & 0.4 & 0.20 \\
& & WD & 4 & 50.8 & 0.0 & 0.75 \\
& & WD + DBH + & 7 & 54.3 & 3.5 & 0.13 \\
& & DBH & \\
& & Null & & & & \\
& & & 3 & 56.7 & 5.9 & 0.04 \\
\hline
\end{tabular}

$\mathrm{C}=$ forest cover; $\mathrm{E}=$ forest edge; $\mathrm{S}=$ shape index; $\mathrm{WD}=$ wood density; $\mathrm{DBH}=$ diameter at breast height; $\mathrm{H}=$ tree height.

degraded (B) and 10 were considerably degraded (C). As for pieces of available trees, 12 were healthy, 13 were partially degraded and four were considerably degraded. Frequencies of wood pieces at each degradation category was dependent of whether the tree was bearing a cavity or was an available tree $\left(\chi^{2}=10.2, \mathrm{df}=2, P=0.005\right)$. Wood density and wood degradation category were highly and negatively correlated ( $r=-0.81, P<0.01$ ) (Supplementary Figure S3).

Campo Flicker cavities were larger than those of the Green-barred Woodpecker (Table 5). Wood density of cavity-tees was not different between the woodpeckers $(t=0.96, P=0.34)$ nor were DBH $(t=-1.77$, $P=0.07)$ and tree height $(t=0.71, P=0.47)$.

\section{Discussion}

We provide the first study assessing the nest-site selection patterns of the Green-barred Woodpecker and the Campo Flicker in a southern temperate forest of Argentina and the first one including quantitative wood density data in the Neotropical region. Our results indicate that these woodpeckers selected trees with soft wood affected by decay processes compared to available wood in other trees within their territories which had higher wood density and less affected by decay processes. This has also been reported for other woodpeckers (Schepps et al. 1999, Matsuoka 2008) including species of the same genus such as Colaptes auratus (Lorenz et al. 2015). Colaptes are considered weak excavators, so their preference for soft wood may be linked to their excavation capabilities. However, because there was not a particular preference for soft wood trees available in the area (e.g., Populus sp., Erythrina crista-galli), the selection of wood softened by decay processes supports the idea that woodpeckers excavate their cavities when the excavation process is facilitated by decay processes (Lorenz et al. 2015). This acquires special relevance in terms of the future conservation policies to be applied in order to allow these populations to endure.

The prediction that areas with greater forest cover and less forest edge would be preferred received weak support for both species. Because of our relatively small sample size, we cannot discard the possibility that a larger sample would support this prediction. On the other hand, the random sampling method might have provided habitats without enough differences to compare. However, these two woodpeckers are adapted to breed in a wide variety of habitats, including semi-open forests, savannas and more enclosed forests (Winkler and Christie 2002, Cockle et al. 2011), which is probably why they excavated cavities in different habitats as available. Moreover, although greater forest cover reduces breeding success, as suggested by other studies (Gow and Wiebe 2014, Tremblay et al. 2014), this may not be the case of our study site (but should be tested), hence, woodpeckers are not selecting these habitats.

Both woodpeckers selected trees of a certain diameter when excavating their cavities, which was different than the diameter of the trees available in the territory. On the one hand, the avoidance of small trees (DBH $<20 \mathrm{~cm}$ ) by both species is probably a result of selecting trees large enough to excavate their cavities. This was more important in the Campo Flicker, most likely because it is a larger size species (Winkler and Christie 2002), hence, it needs larger trees to excavate cavities. Furthermore, both species did not select large trees, considering tree selection probability decreased with size. Because available trees were classified as snags using visual signals (opposed to quantitative wood density data), they may have been above the woodpeckers wood density excavation threshold, hence, they were imprecisely categorized as 'available'. Both species populations in northern Argentina did use larger trees, using the Campo Flicker and the Green-barred Woodpecker 30 and $43 \mathrm{~cm}$ diameter trees, respectively (Cockle et al. 2011). Therefore, there is likely another factor (which we did not measured/control) why the woodpeckers did not select large size trees, rather than size itself.

Although we did not find significant differences regarding used vs. available tree species, woodpeckers completely avoided $S$. buxifolia, a relatively abundant tree species in the study area. We believe differences were not significant because of our relatively low sample size as ongoing studies in the study area indicate these two woodpeckers do not use $S$. buxifolia trees at all. Instead, breeding pairs excavated their cavities mainly in C. tala, another abundant tree (Doumecq and Arenas 2018), selecting snags or dead branches under decay processes. We never observed a $S$. buxifolia snag, and there were only a few individuals which externally seemed under a decay process (A. Jauregui, pers. obs.). 


\section{C. campestris}
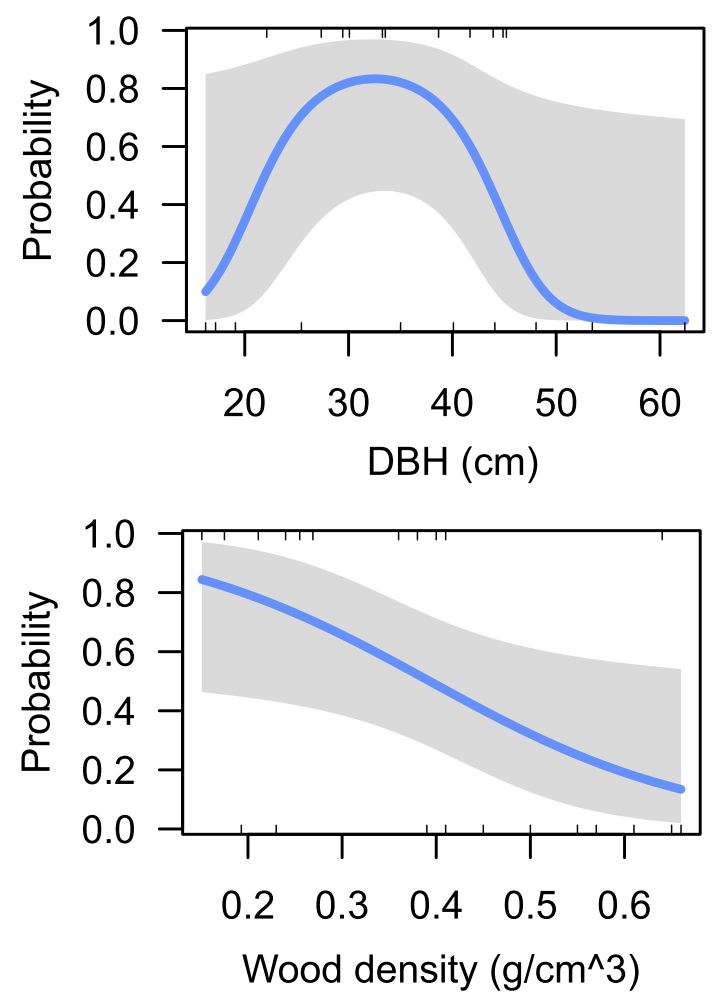

\section{C. melanochloros}
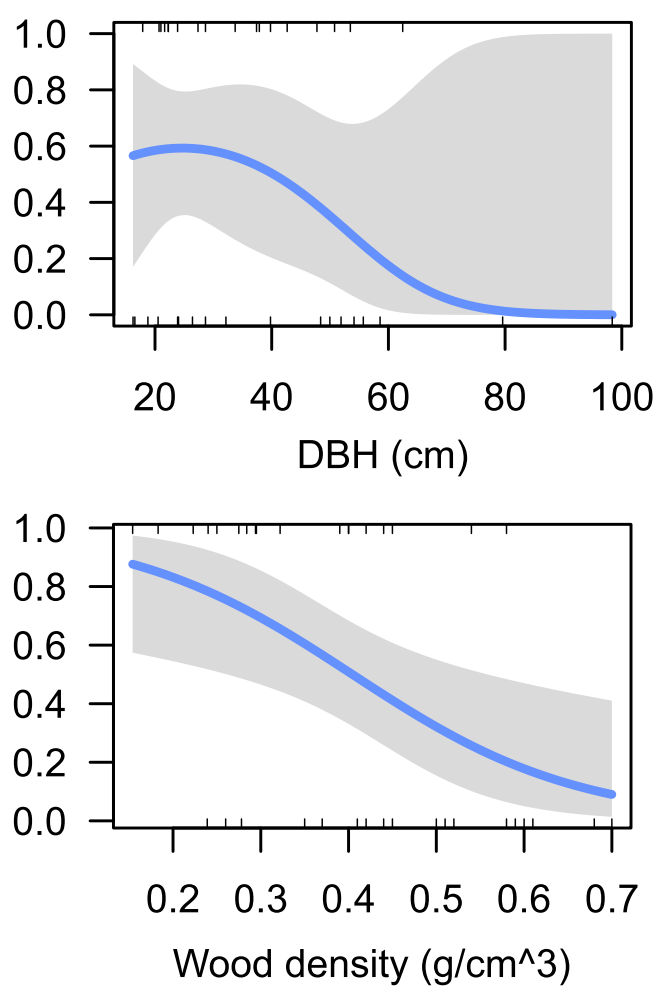

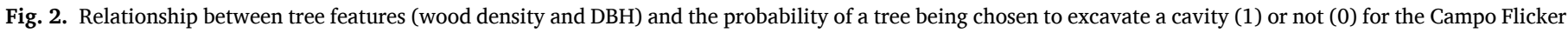

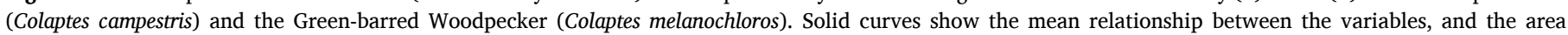

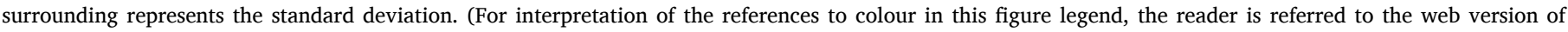
this article.)

\section{Table 4}

Nest-site selection model-averaged estimates, unconditional standard errors, and odds ratio (including 95\% confidence intervals - CI) for the models accounting $90 \%$ of support at the tree scale for two Colaptes woodpeckers. Model averaged was developed using the zero method (see text).

\begin{tabular}{|c|c|c|c|c|c|}
\hline Woodpecker & Parameter & Estimate & SE & Importance & $\begin{array}{l}\text { Odds Ratio } \\
(95 \% \mathrm{CI})\end{array}$ \\
\hline \multirow[t]{4}{*}{ Campo Flicker } & Intercept & 0.92 & 1.33 & - & $\begin{array}{l}2.51 \\
(0.16-12.08)\end{array}$ \\
\hline & DBH & -0.44 & 0.83 & 0.53 & $\begin{array}{l}0.64 \\
(0.11-3.59)\end{array}$ \\
\hline & $\mathrm{DBH}^{2}$ & -1.26 & 1.76 & 0.53 & $\begin{array}{l}0.28 \\
(0.008-10.24)\end{array}$ \\
\hline & WD & -0.42 & 0.65 & 0.36 & $\begin{array}{l}0.66 \\
(0.18-2.42)\end{array}$ \\
\hline \multirow[t]{5}{*}{$\begin{array}{l}\text { Green-barred } \\
\text { Woodpecker }\end{array}$} & Intercept & 0.02 & 0.44 & - & $\begin{array}{l}1.02 \\
(0.41-2.53)\end{array}$ \\
\hline & WD & -1.10 & 0.62 & 0.96 & $\begin{array}{l}0.33 \\
(0.09-1.17)\end{array}$ \\
\hline & DBH & -0.10 & 0.35 & 0.14 & $\begin{array}{l}0.90 \\
(0.44-1.83)\end{array}$ \\
\hline & $\mathrm{DBH}^{2}$ & -0.07 & 0.39 & 0.14 & $\begin{array}{l}0.92 \\
(0.41-2.05)\end{array}$ \\
\hline & $\mathrm{H}$ & 0.09 & 0.30 & 0.14 & $\begin{array}{l}1.10 \\
(0.60-2.01)\end{array}$ \\
\hline
\end{tabular}

$\mathrm{WD}=$ wood density; $\mathrm{DBH}=$ diameter at breast height; $\mathrm{H}=$ tree height.

Therefore, S. buxifolia trees may be resistant to fungal degradation or may not count with organisms (e.g., insects) that degrade their wood, hence, there are no individuals with wood soft enough nor under decay processes to be excavated.

The only important difference between the woodpecker species was that the Campo Flicker excavated larger cavities, most likely because of its greater body size compared to the Green-barred Woodpecker. Given their morphological similarities, and since they are sympatric species, we expected to find differences on the nest-trees and sites features used to excavate cavities in order to avoid resources overlap which could have fitness costs, such as increased predation rates (Martin 1996). However, the Campo Flicker mainly inhabits forests close to open areas but mainly forages on the ground, while the Green-barred Woodpecker is found frequently feeding on the trees within the forest and may sometimes forage on the ground in open areas. Therefore, segregation could be related to different behaviours (Di Bitetti et al. 2010) rather than differences in the location to excavate a cavity.

Forests in our study area were strongly modified in the past century due to selective tree logging focused on medium-sized (DBH $=20-35$ $\mathrm{cm}$ ) and large-sized trees (DBH $>35 \mathrm{~cm}$ ) (Arturi and Goya 2004), and nowadays are mainly composed of small trees (DBH $\leq 20 \mathrm{~cm}$ ), which were not selected by these woodpeckers. On the one hand, small trees within this area are frequently not large enough for woodpeckers to fit their cavities. On the other hand, assuming these species find a tree large enough to excavate, they still need wood under a certain density threshold and affected by decay processes, which makes it appropriate for excavation. Although a study including a larger sample size would be accurate to confirm these patterns, undoubtedly these factors are important for these woodpeckers breeding. We suggest forest management actions should focus on the preservation of forest plots with trees large enough to fit woodpecker cavities and with wood soft enough and under decay processes to ensure the availability of the features preferred by both species. 
Table 5

Features of cavities of the Campo Flicker Colaptes campestris and the Greenbarred Woodpecker C. melanochloros nests belonging to 2017/2018 breeding season. Differences between the species are highlighted in bold. $P=\mathrm{p}$-value.

\begin{tabular}{|c|c|c|c|c|c|c|}
\hline \multirow[t]{2}{*}{ Feature } & \multicolumn{2}{|c|}{$\begin{array}{l}\text { Campo Flicker }(n= \\
13 \text { cavities) }\end{array}$} & \multicolumn{2}{|c|}{$\begin{array}{l}\text { Green-barred } \\
\text { Woodpecker ( } n=18 \\
\text { cavities) }\end{array}$} & \multirow[t]{2}{*}{ Estimate } & \multirow[t]{2}{*}{$P$} \\
\hline & $\begin{array}{l}\text { Mean } \\
\pm \mathrm{SE}\end{array}$ & Range & $\begin{array}{l}\text { Mean } \\
\pm \text { SE }\end{array}$ & Range & & \\
\hline $\begin{array}{l}\text { Cavity } \\
\text { entrance } \\
\text { height } \\
\text { (m) }\end{array}$ & $\begin{array}{l}2.7 \pm \\
0.2\end{array}$ & $1.7-4.2$ & $\begin{array}{l}2.8 \pm \\
0.2\end{array}$ & $0.6-5.8$ & 0.33 & 0.74 \\
\hline $\begin{array}{l}\text { Cavity } \\
\text { depth } \\
(\mathrm{cm})^{*}\end{array}$ & $\begin{array}{l}37.1 \\
\pm 1.4\end{array}$ & $28.2-42.5$ & $\begin{array}{l}33.0 \\
\pm 0.8\end{array}$ & $20.6-42.5$ & - & - \\
\hline $\begin{array}{l}\text { Major } \\
\text { diameter } \\
(\mathrm{cm})\end{array}$ & $\begin{array}{l}6.9 \pm \\
0.1\end{array}$ & $6.5-8.0$ & $\begin{array}{l}7.1 \pm \\
0.1\end{array}$ & $6.2-8.6$ & 1.51 & 0.12 \\
\hline $\begin{array}{l}\text { Minor } \\
\quad \text { diameter } \\
(\mathrm{cm})\end{array}$ & $\begin{array}{l}6.3 \pm \\
0.1\end{array}$ & $5.8-8.1$ & $\begin{array}{l}6.1 \pm \\
0.1\end{array}$ & $5.0-7.2$ & -1.17 & 0.24 \\
\hline $\begin{array}{l}\text { Cavity } \\
\text { length } \\
(\mathrm{cm})^{*}\end{array}$ & $\begin{array}{l}13.3 \\
\pm 0.4\end{array}$ & $9.0-20.5$ & $\begin{array}{l}11.5 \\
\pm 0.3\end{array}$ & $8.5-16.0$ & - & - \\
\hline $\begin{array}{l}\text { Cavity } \\
\text { branch } \\
\text { diameter } \\
(\mathrm{cm})\end{array}$ & $\begin{array}{l}26.4 \\
\pm 1.3\end{array}$ & $18.8-42.0$ & $\begin{array}{l}22.7 \\
\pm 0.8\end{array}$ & $16.9-41.4$ & -1.25 & 0.20 \\
\hline $\begin{array}{l}\text { Cavity } \\
\text { volume } \\
\text { (1) }\end{array}$ & $\begin{array}{l}6.0 \pm \\
0.6\end{array}$ & $1.6-24.0$ & $\begin{array}{l}3.4 \pm \\
0.2\end{array}$ & $1.2-15.9$ & -3.05 & 0.005 \\
\hline $\begin{array}{l}\text { Cavity } \\
\text { location }\end{array}$ & \multicolumn{2}{|c|}{$\begin{array}{l}\text { Main stem (9), } \\
\text { primary branch (3), } \\
\text { secondary branch (1) }\end{array}$} & \multicolumn{2}{|c|}{$\begin{array}{l}\text { Main stem (9), } \\
\text { primary branch (5), } \\
\text { secondary branch (4) }\end{array}$} & 1.53 & 0.46 \\
\hline
\end{tabular}

* Not statistically compared since they were correlated to cavity volume $(r=$ 0.71 and 0.69 , respectively).

\section{CRediT authorship contribution statement}

Adrián Jauregui: Conceptualization, Data curation, Formal analysis, Investigation, Methodology, Resources, Software, Supervision, Validation, Visualization, Writing - original draft, Writing - review \& editing. Sabrina Andrea Rodríguez: Investigation, Methodology, Resources, Validation, Writing - original draft, Writing - review \& editing. Lucas Nahuel González García: Data curation, Investigation, Software. Exequiel Gonzalez: Data curation, Investigation, Visualization. Luciano Noel Segura: Conceptualization, Funding acquisition, Investigation, Project administration, Resources, Supervision, Validation, Writing - original draft, Writing - review \& editing.

\section{Declaration of Competing Interest}

The authors declare that they have no known competing financial interests or personal relationships that could have appeared to influence the work reported in this paper.

\section{Acknowledgments}

We are grateful to M.L. Shaw for allowing us to conduct this study in "Luis Chico". We thank J. A. Rossi and M. N. Uménico for the help during field work. We thank F.X. Palacio for the help in data interpretation and analysis, A. Schaaf for helpful comments on a previous version of this manuscript and CONAE for providing the satellite image used for this study. We appreciate the improvements in English usage made by Colin Tiernan and the comments made by two anonymous reviewers on a previous version of this manuscript.

Ethics. Research permits to conduct the study were granted by the local environmental authority (OPDS \#17717, Dirección de Áreas Naturales Protegidas, Buenos Aires province, Argentina).
Funding and permits. This study was financially supported by the "Fondo para la Investigación Científica y Tecnológica (Agencia Nacional de Promoción Científica y Tecnológica)”, under Grant \# 2014-3347.

\section{Appendix A. Supplementary data}

Supplementary data to this article can be found online at https://doi. org/10.1016/j.foreco.2021.119723.

\section{References}

Anderson, E.C., LaMontagne, J.M., 2016. Nest selection by Red-headed Woodpeckers across three spatial scales in an urban environment. Urban Ecosyst. 19, 297-314.

Arturi, M.F., Goya, J.F., 2004. Estructura, dinámica y manejo de los talares del NE de Buenos Aires. In: Arturi, M.F., Frangi, J.L., Goya, J.F. (Eds.), Ecología y Manejo De Los Bosques De Argentina. Edulp, La Plata, pp. 1-23.

Asner, G.P., Knapp, D.E., Broadbent, E.N., Oliveira, P.J.C., Keller, M., Silva, J.N., 2005. Selective logging in the brazilian amazon. Science 310, 480-482.

Atencia, M. D (2003). Densidad de Maderas (kg/m3). Argentinian Government Technichal Report. https://www.inti.gob.ar/publicaciones/descargac/365.

Bates, D., Maechler, M., Bolker, B., Walker, S., 2015. Fitting Linear Mixed-Effects Models Using lme4. J. Stat. Soft. 67, -48. https://doi.org/10.18637/jss.v067.i01.

Battin, J., Lawler, J.J., 2006. Cross-scale correlations and the design and analysis of avian habitat selection studies. Condor 108, 59-70.

Berl, J.L., Edwards, J.W., Bolsinger, J.S., Katzner, T.E., 2014. Survival of Red-headed Woodpeckers' (Melanerpes erythrocephalus) nests in northern New York. Wilson J. Ornithol. 126, 700-707.

Bonnot, T.W., Millspaugh, J.J., Rumble, M.A., 2009. Multi-scale nest-site selection by Black-backed Woodpeckers in outbreaks of mountain pine beetles. For. Ecol. Manag. 259, 220-228.

Brightsmith, D.J., 2005. Competition, predation and nest niche shifts among tropical cavity nesters: ecological evidence. J. Avian Biol. 36, 74-83.

Burnham, K.P., Anderson, D.R. (Eds.), 2002. Model selection and multimodel inference: a practical information-theoretic approach. Springer-Verlag, New York.

Chave, J., Coomes, D., Jansen, S., Lewis, S.L., Swenson, N.G., Zanne, A.E., 2009. Towards a worldwide wood economics spectrum. Ecol. Lett. 12, 351-366.

Chotprasertkoon, T., Pierce, A.J., Savini, T., Round, P.D., Sankamethawee, W., Gale, G. A., 2017. Influence of vegetation cover on nest cavity selection and nesting success of White-rumped Shamas (Copsychus malabaricus): an experimental test. Wilson J. Ornithol. 129, 727-741.

Cockle, K.L., Martin, K., Wiebe, K.L., 2011. Selection of nest trees by cavity-nesting birds in the Neotropical Atlantic Forest. Biotropica 43, 228-236.

Cockle, K.L., Martin, K., Robledo, G., 2012. Linking fungi, trees, and hole-using birds in a Netotropical tree-cavity network: pathways of cavity production and implications for conservation. For. Ecol. Manag. 264, 210-219.

Deng, W.-H., Gao, W., 2005. Edge effects on nesting success of cavity-nesting birds in fragmented forests. Biol. Conserv. 126 (3), 363-370.

Denny, R., Summers, R.W., 1996. Nest-site selection, management and breeding success of Crested Tits Parus cristatus at Abernethy Forest, Strathspey. Bird Study 43, 371-379.

Di Bitetti, M.S., De Angelo, C.D., Di Blanco, Y.E., Paviolo, A., 2010. Niche partitioning and species coexistence in a Neotropical felid assemblage. Acta Oecol. 36, 403-412.

Dias, R.I., Webster, M.S., Goedert, D., Macedo, R.H., 2013. Cooperative breeding in the Campo Flicker I: breeding ecology and social behavior. Condor 115, 847-854.

Domokos, E., Cristea, V., 2014. Effects of managed forests structure on woodpeckers (Picidae) in the Niraj valley (Romania): woodpecker populations in managed forests. North-west. J. Zool. 10, 110-117.

Dormann, C.F., Elith, J., Bacher, S., Buchmann, S., Carl, G., Carré, G., García Márquez, J. R., Gruber, B., Lafourcade, B., Leitão, P.J., Münkenmüller, T., et al., 2013. Collinearity: a review of methods to deal with it and a simulation study evaluating their performance. Ecography 36, 27-46.

Doumecq, M.B., Arenas, P.M., 2018. ¿Qué madera es buena para leña? Conocimiento botánico local en "leñeras" del partido de La Plata (Buenos Aires, Argentina). Boletín Soc. Arg. Bot. 53, 491-506.

Gonzalez, E., Jauregui, A., Segura, L.N., 2019. Breeding biology of the Yellow-browed Tyrant (Satrapa icterophrys) in south temperate forests of central Argentina. Wilson J Ornithol. 131, 534-542.

Götmark, F., Blomqvist, D., Johansson, O.D., Bergkvist, J., 1995. Nest site selection: a trade-off between concealment and view of the surroundings? J. Avian Biol. 26 305-312.

Gow, E.A., Wiebe, K.L., 2014. Determinant of parental care and offspring survival during the post-fledging period: males care more in a species with partially reversed sex roles. Oecologia 175, 95-104.

Grueber, C.E., Nakagawa, S., Laws, R.J., Jamieson, I.G., 2011. Multimodel inference in ecology and evolution: challenges and solutions. J. Evol. Biol. 24, 699-711.

Jauregui, A., 2020. Selección de sitios de nidificación y efecto del hábitat en el éxito reproductivo de Colaptes campestris (Carpintero Campestre) y Colaptes melanochloros (Carpintero Real) (Aves: Picidae) en talares bonaerenses. Facultad de Ciencias Naturales y Museo. Universidad Nacional de La Plata, La Plata, Argentina.

Jelinski, D.E., 1991. On the use of chi-square analyses in studies of resource utilization. Can. J. For. Res. 21, 58-65.

Jones, J., 2001. Habitat selection studies in avian ecology: a critical review. Auk 118, $557-562$. 
Kozma, J.M., Kroll, J.A., 2011. Woodpecker nest survival in burned and unburned managed Ponderosa Pine forests of the northwestern United States. Condor 114, 173-184.

Lammertink, M., Estrada, A.R., 1995. Status of the Ivory-billed Woodpecker Campephilus principalis in Cuba: almost certainly extinct. Bird Conserv. Int. 5, 53-59.

Le Tortorec, E., Helle, S., Käyhkö, N., Suorsa, P., Huntha, E., Hakkarainen, H., 2013. Habitat fragmentation and reproductive success: a structural equation modelling approach. J. Anim. Ecol. 82, 1087-1097.

Lorenz, T., Vierling, K.T., Johnson, T.R., Fischer, P.C., 2015. The role of wood hardness in limiting nest site selection in avian cavity excavators. Ecol. Appl. 25, 1016-1033.

Martin, T.E., 1996. Fitness costs of resource overlap among coexisting bird species. Nature 380, 338-340.

Matsuoka, S., 2008. Wood hardness in nest trees of the Great Spotted Woodpecker Dendrocopos major. Ornithological Science 7, 59-66.

Nappi, A., Drapeau, P., Leduc, A., 2015. How important is dead wood for woodpeckers foraging in eastern North American boreal forests? For. Ecol. Manag. 346, 10-21.

Nyirenda, V.R., Chewe, F.C., Chisha-Kasumu, E., Lindsey, P.A., 2016. Nest site selection by sympatric cavity-nesting birds in miombo woodlands. Koedoe 58, a1359.

Ojeda V., A. Schaaf, T. Altamirano, B. Bonaparte, L. Bragagnolo, L. Chazarreta, K. Cockle, R. Dias, F. Di Sallo, J. T. Ibarra, S. Ippi, A. Jauregui, J. Jimenez, M. Lammertink, F. López, M. G. Núñez Montellano, M. De la peña, L. Rivera, C. Vivanco, M. Santillán, G. Soto, P. Vergara, A. Wynia, N. Politi (2021). Latitude does not influence cavity entrance orientation of South American avian excavators. Auk 138:1-14. https://doi. org/10.1093/ornithology/ukaa064.

QGIS Development Team. [online] (2018). QGIS Geographic Information System. Open Source Geospatial Foundation Project. <http://qgis.osgeo.org/>.

R Development Core Team [online] (2018). R: A language and environment for statistical computing. R Foundation for Statistical Computing, Vienna, Austria. <http://www. Rproject.org/>.

Rodríguez, S.A., Cristiano, P.M., Lezcano, O.A., Suirezs, T.M., Díaz Villa, M.V.E., Bucci, S. J., Goldstein, G., Campanello, P.I., 2021. Crown structural properties, wood density and liana load: influence on growth and mortality in subtropical forests. Can. J. For. Res. 51 (1), 111-121. https://doi.org/10.1139/cjfr-2020-0002.

Rutledge, D. 2003: Landscape indices as measures of the effects of fragmentation: can pattern reflect process? DOC Science Internal Series 98. Department of Conservation, Wellington. 27 p.

Schepps, J., Lohr, S., Martin, T.E., 1999. Does tree hardness influence nest-tree selection by primary cavity nesters? Auk 116, 658-665.

Scholz, F.G., Bucci, S.J., Goldstein, G., Meinzer, F.C., Franco, A.C., Miralles-Wilhelm, F., 2007. Biophysical properties and functional significance of stem water storage tissues in neo-tropical savanna trees. Plant Cell Environ. 30, 236-248.

Segura L. N. and J. C. Reboreda. 2012. Nest survival rates of Red-crested Cardinals increase with nest age in south temperate forests of Argentina. J. Field Ornithol. 83: 343-350.

Tremblay, J.A., Ibarzabal, J., Savard, J.-P.-L., Wilson, S., 2014. Influences of old coniferous habitat on nestling growth of Black-backed Woodpeckers Picoides arcticus. Acta Ornithol. 49, 273-279.

van Gelder, H.A., Poorter, L., Sterck, F.J., 2006. Wood mechanics, allometry, and lifehistory variation in a tropical rain forest tree community. New Phytol. 171, 367-378.

Vierling, K.T., Lentile, L.B., Nielsen-Pincus, N., 2008. Preburn characteristics and woodpecker use of burned coniferous forest. J. Wild. Manag. 72, 422-427.

Wiebe, K.L., Swift, T.L., 2001. Microclimate of tree cavity nests: is it important for reproductive success in northern flickers? Auk 118, 412-421.

Wightman, C.S., Saab, V.A., Forristal, C., Mellen-McLean, K., Markus, A., 2010. Whiteheaded woodpecker nesting ecology after wildfire. J. Wild. Manag. 74, 1098-1106.

Winkler, H., Christie, D.A., 2002. Family Picidae (Woodpeckers). In: del Hoyo, J., Elliot, A., Sargatal, J. (Eds.), Handbook Of The Birds Of The World. Vol. 7 Jacamars to Woodpeckers. Lynx Ediciones, Barcelona, pp. 296-555.

Zhu, X., Srivastava, D.S., Smith, J.N.M., Martin, K., 2012. Habitat selection and reproductive success of Lewi's Woodpecker (Melanerpes lewis) at its northern limit. PLoS One 7, e44346. 